Reference Services Review, 1990, v. 18, n.4, p. 49-63.

ISSN: 0090-7324

DOI: $10.1108 / \mathrm{eb} 049106$

http://www.emeraldinsight.com/

http://www.emeraldinsight.com/journals.htm?issn=0090-7324\&volume=18\&issue=4

http://www.emeraldinsight.com/journals.htm?issn=0090-7324\&volume=18\&issue $=4 \&$ articleid=1696185\&show=ab

stract

(C) 1990 MCB UP Ltd

\title{
Terrorism: Current Readings
}

\section{Magda El-Sherbini}

Terrorism is not a new phenomenon in human life. It existed during Biblical times when Joseph, the seventeen-year-old son of Jacob, was kidnapped and sold into slavery by his jealous brothers. Although terrorists have been active throughout history, it is only recently that we have seen an increase in scholarly interest in the phenomenon of terrorism. One reason for this is the fact that terrorist activities have increased dramatically since the 1960s. Everyday we read in the newspapers and hear on radio and television details of the latest terrorist outrage. Many American colleges and universities now offer a course or two on terrorism as a part of their curriculum.

Since terrorism has become an attractive topic of study for social scientists, especially political scientists, sociologists, and psychologists, the literature has grown so large that readers cannot absorb it all. The subject has been approached from almost every conceivable angle. Studies have been made of terrorist organizations, terrorist personalities, terrorist tactics, and specific terrorist incidents. Some authors have looked at the subject from an historical perspective, while others concentrate on the political, psychological, or sociological aspects. There are books and articles on the behavioral aspects of the problem as well as the implications of terrorist acts on domestic and international law.

This essay presents selected current readings on the subject of terrorism. It includes books, periodicals, encyclopedias and dictionaries, directories, bibliographies, and database files in the English language dating from 1985 to the present. The literature has been classified into eight broad categories: definition of terrorism, general works on terrorism, psychological aspects of terrorism, religious aspects of terrorism, combating terrorism, periodicals, online databases, and bibliographies.

\section{Definition of Terrorism}

Although the use of terror has been around since early human history, arriving at a comprehensive and definitive definition of the word "terrorism" is virtually impossible. The reason for this is that the terms pertaining to terrorism are constantly changing depending on from which side of the ideological spectrum they are viewed. Fortunately, several reference sources have defined the term from different points of view. John Richard Thackrah, in Encyclopedia of Terrorism and Political Violence (1987), states that "terrorism has neither a precise definition nor one which is widely acceptable. The imprecise nature of the term means that it can be applied to almost any set of fear-producing actions to serve a variety of purposes. More generally, it can 
apply to similar acts of violence, kidnapping and hijackings. Political sociologists argue that no definition can be reached because the very process of definition is itself part of the wider contestation of ideologies or political objectives." (p. 54) In this reference tool, Thackrah analyzes the term in interesting sequences and provides more than sixty quotations that help to define terrorism. The encyclopedia is arranged alphabetically, with each entry consisting of from 500 to more than 1,000 words. The number of biographical articles, however, is limited due to the great emphasis that has been given to biographies of terrorists in other literature. It includes an index, a list of abbreviations and acronyms, and a bibliography that will be very useful to researchers interested in finding additional literature on the subject. This encyclopedia would be a valuable addition to the reference collections of both academic and public libraries.

Political Terrorism, a New Guide to Actors, Authors, Concepts, Data Bases, Theories and Literature (Rev., expanded and updated ed., 1988) was written by Alex P. Schmid and Albert J. Jongman. In this work, the authors give a very detailed definition of "terrorism." In the first edition of the book, which was published in 1984, the authors devoted more than one hundred pages to conceptual questions of terrorism, citing and discussing more than one hundred definitions of the term as given by academic institutions and government agencies, such as the United States Congress, the Central Intelligence Agency, and the Federal Bureau of Investigation. This second edition of the book is even more useful in that it not only gives definitions but also has a chapter on the typologies of terrorism. It includes a comprehensive bibliography and an updated "World Directory of Terrorist and Other Organizations Associated With Guerrilla Warfare, Political Violence and Protest." This directory, an important work in itself, covers state actors and state-supported actors along with non-state actors in a single list of perpetrators of political violence. Contrary to the list included in the 1984 edition of this research guide, the present list excludes victim groups that do not engage in violence themselves. The list has been updated from 1983 to the spring of 1987. It includes about 3,000 groups, parties, movements, and organizations, and is structured on a country-by-country basis.

Another directory that deserves to be mentioned is George Rosie's Directory of International Terrorism (1987). Although this work is a directory, the introduction includes a detailed definition of terrorism, plus information on the history of modern terrorism, categories of terrorism, international terrorism and the international media, terrorism and weapons technology, terror states and the rule of law, and hijacking and attacks on air transports. The directory itself is also significant. It concentrates on the most recent actors, persons, and terrorist activities. The author has tried to gather as much information about each terrorist as he could. This must have been no easy task since, as we all know, terrorists and their groups do not usually divulge their secrets to outsiders. The articles range in length from one paragraph to two pages. The directory also has a good selected bibliography.

One other reference work that defines terrorism is Parry and Grant Encyclopedic Dictionary of International Law (1986), edited by Clive Parry and others, with assistance from some members of the Scottish Group of International Lawyers. Although the articles are brief, each one refers the reader to other related books.

\section{General Works on Terrorism}

Countless general studies on terrorism provide a definition, history, and analysis of the subject. Paul Wilkinson, Professor of International Relations at the University of Aberdeen, wrote 
Terrorism and the Liberal State (2nd ed., rev., extended, and updated, 1986). In this extensively revised second edition, Wilkinson tries to improve our understanding of the problem of terrorism by viewing it against the background of contemporary international relations and continuing ideological conflicts. The book concerns itself with "three sets of problems: the relation of terrorism to the basic values and processes of liberal democracies; the underlying and precipitative causes of terrorist action and the internal and external defences against terrorism open to liberal government; and the growth and implications of international terrorism." (publisher's note) It is well-indexed and includes a brief guide to further readings as well as comprehensive notes and references. This work is a must for all academic and public libraries.

Paul Wilkinson has also worked with Alasdair M. Stewart in editing Contemporary Research on Terrorism (1989). This book includes papers presented at the International Academic Research Conference on Research on Terrorism which was held at Aberdeen University under the auspices of the Department of Politics and International Relations, 15-17 April 1986. The collection does not include all of the papers presented at the conference, but rather contains a selection of papers that reflect the editors' own areas of interest. In the forward, Mr. Wilkinson describes a terrorist as one "who tries to terrify people into doing what he or she wants. For the politically motivated terrorist the object is generally to create a climate of fear among a wider target group than the immediate victims of the violence." (p. xi) The book contains six general topics: definitional and conceptual aspects, moral and religious aspects, trends and patterns in the history of terrorism, behavioral aspects, terrorism and the media, and national and international responses. Each topic contains several essays written by professionals in the field. The notes, selected English language bibliography, and index are comprehensive. This work is recommended for all research as well as public libraries.

Walter Laqueur, another expert on the topic of terrorism, is chair of the International Research Council of the Center for Strategic and International Studies in Washington, D. C, professor in the Department of Government at Georgetown University, and editor of the Journal of Contemporary History. He is the author of Guerrilla, Weimar, The Terrible Secret, World of Secrets: The Uses and Limits of Intelligence, and many other publications and essays. Among his works, two are especially worthy of mentioning here. The first, The Age of Terrorism (1987), is one of the most important and comprehensive works on the history of terrorism. It is a revised and expanded study of national and international political violence, based on the author's classic work Terrorism (1978). In this new edition, the first two chapters on the origins of terror and the philosophy of the bomb are unchanged. However, new information found in this edition includes a review of ethnonational, international, and ideological terrorism; sections on Euro-terrorism and narco-terrorism; and a chapter on "the image of the terrorist in literature and the cinema." Laqueur's book received excellent reviews in Library Journal, Economist, New York Review of Books, and several other journals. It includes a bibliography, notes, a list of abbreviations, and a comprehensive index. It is full of erudition and insight and is a most welcome addition to the expanding literature on terrorism.

The second of Laqueur's works is The Terrorism Reader: A Historical Anthology (Rev. ed., 1987), a revised edition edited by Laqueur and Yonah Alexander. Alexander is the editor-in-chief of Terrorism, the leading journal in the field, and is director of the Institute for Studies in International Terrorism at the State University of New York, Oneonta, New York. This book gives an historical analysis of terrorism from ancient times through the present. Alexander outlines the tremendous growth in state-sponsored terrorism around the world, while Laqueur evaluates the efficacy of achieving radical change through violent means. This revised edition includes a new 
section on terrorism today, which discusses such topics as the future of the PLO, nuclear terrorism, official U.S. responses to terrorism, the modern phenomenon of women as terrorists, and psychological and sociological interpretations of terrorism. This book is an essential reference source on the history of political violence.

Christopher Dobson and Ronald Payne have also written many books about terrorism. Among their publications, two will be included in this essay: The Never-Ending War: Terrorism in the 80's (1989) and War Without End: The Terrorists: An Intelligence Dossier (Updated ed., 1987). Although these two books are not as analytical and theoretical as Laqueur's The Age of Terrorism, they are comprehensive in coverage. They provide a retrospective look at the activities, tactics, and techniques of the most active terrorist groups during the 1970s and 1980s. The authors have succeeded in discussing some of the lesser-known organizations in Europe, India, Sri Lanka, and Latin America. War Without End includes sections called "Who's Who of Terror" and "Chronology of Terror: 1968-1985." Both books include selective bibliographies and are indexed. They are recommended for general readers.

The question of how to distinguish between freedom fighters and terrorists has been addressed in the book Terrorists or Freedom Fighters (1986), edited by Ely Tavin and Yonah Alexander. This work was published in cooperation with the Department of Education and Culture, the World Zionist Organization, and the State University of New York. It consists of a collection of essays written by several specialists in the field. The authors provide an excellent definition of the word "terrorist" and they examine the differences between "terrorist" and terms such as "people's war," "crusaders," "commanders," and "guerrillas." The book is divided into six parts: an overview, international perspective, Jewish perspective, third world perspective, Western experience, and future perspective. In the conclusion, the authors try to emphasize the difference between terrorists and freedom fighters by defining characteristics to be considered in analyzing the meaning of each term. This is a readable book that will be of value to researchers.

Revelations regarding the United States involvement in the Iran-Contra affair fueled criticism of the Reagan administration. Noam Chomsky has written two works which reflect this criticism, The Culture of Terrorism (1988) and Pirates \& Emperors .International Terrorism in the Real World (1987). In The Culture of Terrorism, Chomsky criticizes U.S. foreign policy, asserting that it is obvious from documentary and historical records that "the U.S. international and security policy, rooted in the structure of power in the domestic society, has as its primary goal the preservation of ... the Fifth Freedom." He defines the "Fifth Freedom" as the right "to rob, to exploit, and to dominate, to undertake any course of action to ensure that existing privilege is protected and advanced." Chomsky completely disagrees with the U.S. government's clandestine operations in other countries, operations intended to influence the political history of countries in favor of U.S. economic and political interests. He uses Central America and the Iran-Contra Affair to illustrate his point. Significantly, he uses the word "terrorism" in a general sense to refer to any intervention, even by a government, in the affairs of another nation.

In Pirates \& Emperors, Chomsky states that "the [Reagan] administration was committed to three related policies ...: 1) transfer of resources from the poor to the rich;2) a massive increase in the state sector of the economy in the traditional American way, through the Pentagon system ...; and 3) a substantial increase in U.S. intervention, subversion, and international terrorism." (p. 7) The main concern in this book is acts of international terrorism (referring to acts committed by the Reagan administration) in the real world, focusing the attention on the Mediterranean region. However, Chomsky also mentions that the major victims of international terrorism in the past several decades (before 1986) have been Cubans, Central Americans, and inhabitants of Lebanon. 
He divides his book into three subject areas: thought control, the case of the Middle East; Middle East terrorism and the American ideological system; and Libya/United States relations.

Terrorist Myths: Illusion, Rhetoric, and Reality (1989) by Peter C. Sederberg is another general overview of terrorism. In this work, the author tries to identify some of the prominent myths common to the analysis of terror and to extricate what may be useful to our understanding from the illusion and rhetoric that clouds our thinking. To approach this goal, Sederberg discusses politics and violence, the meaning of terrorism, perpetrators of terrorism, understanding the psychology and social-psychology of terrorist acts, and international terrorist conspiracies. He also investigates the complex problems of terrorist networks and sponsors, terrorism and democracy, and what is to be done. Useful notes follow each chapter.

The next two books to be considered are Terrorism, Ideology and Revolution (1986) and Terrorism and National Liberation (1988). Terrorism, Ideology and Revolution, edited by Noel O'Sullivan, is a source of political theory, political science, and history of modern terrorism, with the historical aspect receiving the greatest emphasis. In the final essay of the book, "Terrorism and International Order," Paul Wilkinson emphasizes the "hydra-headed" character of contemporary terrorist phenomena. Terrorism and National Liberation, edited by Hans Köchler, consists of a selection of papers that were presented at the International Conference on the Question of Terrorism organized in Geneva, Switzerland, 19-21 March 1987, by the International Progress Organization. The papers were written by experts in the fields of philosophy, sociology, political science, and international law. Topics included are the history and types of terrorism, state terrorism and liberation movements, the media and western conception of terrorism, and die question of terrorism within the framework of international law. The papers are published in their original language, English or French. Both of these books are recommended for general readers.

Martin Slann and Bernard Schechterman are specialists in political science. They have edited a book entitled Multidimensional Terrorism (1987). In this work, die authors try to cover the basic aspects of terrorism, including both theoretical pieces and case studies. Part one focuses on the goals and motivations of terrorists, part two covers the dimensions of terrorism, and part three presents several case studies. The list of contributors provides brief information about each author. Detailed notes follow each chapter.

Terrell E. Arnold is a consultant on terrorism and crisis management to the Department of State, as well as a consultant of several private firms. He has also served on the Vice President's Task Force on Combating Terrorism. In his book, The Violence Formula: Why People Lend Sympathy and Support to Terrorism (1988), he discusses recent violent political activity and ways to deal with it. Arnold is also a co-author with Moorhead Kennedy of Think About Terrorism: The New Warfare (1988), a general work about various aspects of terrorism, ranging from defining terrorism to what can be done to deal with the international terrorist crisis.

Arnold again, along with Neil C. Livingstone, edited a work entitled Fighting Back: Winning the War Against Terrorism (1986). Livingstone is a well-known Washington-based consultant, writer, and television commentator on terrorism and national security subjects . Fighting Back is composed of a group of comprehensive articles that address the varied causes of terrorism, its international linkage, and the ways in which terrorism and its effects might be alleviated. Beyond the Iran-Contra Crisis: The Shape of U.S. Anti-Terrorism Policy in the Post-Reagan Era (1988), another work edited by Arnold and Livingstone, is a compilation of essays written by experts regarding the impact of the Iran-Contra scandal on U.S. anti-terrorism policies and institutions. The articles include information on the evolution of U.S. anti-terrorism policy; the National Security Council and the Iran-Contra crisis; hostage taking; Lebanon, 
terrorism and future policy; the raid on Libya and the use of force in combating terrorism; special operations reform in the Reagan administration; new media strategies for addressing terrorism; low-intensity terrorism against technological infrastructure; managing the crisis of hostage families; the Iran-Contra crisis and its impact on U. S. -Israeli counter-terror ism cooperation; counter-terrorism as enterprise; new directions in using the law to combat terrorism; and extraterritorial apprehension as a proactive counter-terrorism measure. This extensive work should make an important contribution to the public understanding of terrorism.

Michael Stohl, a professor and director of the Graduate Studies Department of Political Science at Purdue University, is the author of more than 40 articles and book chapters on political violence, terrorism, human rights, and U.S. foreign policy. He is also an editor or co-editor of many books. Among them is The Politics of Terrorism (3rd ed., rev. and expanded, 1988), which gives us the major theories, concepts, strategies, ideologies, practices, and implications of contemporary terrorism. The contributors focus on the concepts and practices of terrorism in the process of politics. This third edition features the addition of six new chapters (two in part I and four in part II). The additions in part I focus on typologies and state terrorism in international affairs. The additions in part II are the analysis of domestic and international terrorism by the Federal Bureau of Investigation and the Department of State, and the analysis of terrorism within Latin America, the Middle East, and the United States. The chapters on Western Europe and Sub-Saharan Africa as well as the introduction and conclusion have been revised and expanded. The book is well written and is a good source for academic libraries.

Michael Stohl has also edited, in cooperation with Robert O. Slater, Director of Research, Defense Intelligence College in Washington, D.C., Current Perspectives on International Terrorism (1988), a collection of papers that were presented at a conference on International Terrorism held in December 1985 and sponsored by the Defense Academic Research Support Program (DHRSP). The contributors present the current thinking of leading international scholars on key aspects of terrorism. Although all of the papers are written by experts, Brian Jenkins' "Future Trends in International Terrorism" contains the most interesting analysis. Jenkins concluded his paper by making the following predictions: terrorists will escalate their violence and their attacks will become more indiscriminate; terrorism will become institutionalized as a mode of armed conflict for some, no less legitimate than other modes of conflict; the media will increase its ability to cover terrorist incidents; and the increasing level of terrorism will become an accepted fact of contemporary life. In general, this book will make fascinating reading for government policy makers and scholars alike.

A third book edited by Michael Stohl, this one with George A. Lopez, is Terrible Beyond Endurance?: The Foreign Policy of State Terrorism (1988). In this book, the authors illustrate the various forms that terrorism may take and the structural causes and consequences of state terrorism. The volume is divided into four sections: the structure of terrorism, the United States and state terrorism, regions and state terrorism, and international law and the future. The notes and index add value to the book. These three books by Michael Stohl and his co-editors are valuable resources for special as well as academic libraries.

Another work that focuses on case studies of terrorism in specific states or regions is The Politics of Terrorism: Terror as a State and Revolutionary Strategy (1989), edited by Barry Rubin, a fellow at the Johns Hopkins Foreign Policy Institute (FPI) and director of the FPI's program for the study of international terrorism. He is also a senior research fellow at the Washington Institute for Near East Policy. This work is the first of a series of studies focusing on different aspects of international terrorism; terrorism in Argentina, the Middle East, Egypt, Iran-Iraq, Peru, and South 
Africa; and a contemporary survey. It is different from Stohl's work, The Politics of Terrorism, in that Rubin concentrates only on terrorism in specific countries.

Richard Falk's Revolutionaries and Functionaries: The Dual Face of Terrorism (1988) is another useful and readable book that offers a response to counter-terrorism. Falk concentrates on the interaction between revolutionary violence and the United States government. He argues that standard tactics and weaponry used by all sides in political conflicts in the world today possess a terrorist character. For example, Soviet tactics in Afghanistan have been clearly terrorist in nature, as have Soviet preparations for nuclear war. As an American, the author focuses on the commonly held theory that what the American government does violently unto others is legitimate counter-terrorism. The emphasis in the book is on impermissible forms of political violence regardless of die identity of the actor. The selective bibliography and notes add value to the work.

Two other general works on terrorism are Alchemists of Revolution: Terrorism in the Modern World (1987) by Richard E. Rubenstein and Invisible Armies: Terrorism into the 1990's (1987) by Stephen Segaller. Alchemists of Revolution provides us with an insider's feel for the subject of terrorism and an understanding of terrorism as an historical and human activity. Invisible Armies discusses political terrorism as a practical problem in politics. Both works are objective, wide-ranging, and readable.

The following books provide a reasonably comprehensive, if largely derivative, overview of the general issue of terrorism. Terrorism as State-Sponsored Covert Warfare (1986) was written by Ray S. Cline, a former deputy director of the CIA, and Yonah Alexander. It was published in cooperation with the Center for Strategic and International Studies, Georgetown University, and is based on a study prepared by the Department of the Army in 1985. The authors discuss the phenomenon of terrorism sponsored by other countries, and in their analysis they mention mat 80 percent of all terrorist incidents are inspired by the Soviet Union. Grant Wardlaw's Political Terrorism: Theory, Tactics, and Counter-Measures ( $2^{\text {nd }}$ ed., rev. and extended, 1989) is another outstanding general work that provides a concise, comprehensive, sensible, and liberal analysis of terrorism. Wardlaw is a psychologist by training and a criminologist by profession. He provides useful chapters on different policy problems, the role of the media, military response, national and international legal processes, intelligence functions (in which is included a very interesting analysis of terrorist aims and techniques), and hostage negotiations. Terrorist activity in Europe is discussed in The Threat of Terrorism (1988). This work is a collection of essays edited by Juliet Lodge in which the authors effectively present case studies on Britain, West Germany, Italy, Spain, the Netherlands, Belgium, and France. Another collection of essays written by British social scientists on the occasion of the attack on Libya by the United States in April 1986 is Terrorism and International Order (1986). The authors, Lawrence Freedman, Christopher Hill, Adam Roberts, R.J. Vincent, Paul Wilkinson, and Philip Windsor, investigate the relationship between terrorism and international order. Their main concern is the reaction of international society to terrorist activities. Adam Roberts presents interesting evidence to show that terrorist acts and the alarm that they cause are not a new feature of international policies.

The goal of any legal criminal process in a civilized society is to punish terrorists for their crimes. John F. Murphy tries, in Punishing International Terrorists: The Legal Framework for Policy Initiatives (1985), to explore both law and practice regarding the punishment of terrorists. The first part of his study considers the legal framework of the process. This legal framework includes international law, the law of the United States, and the law of selected foreign countries. The second part of the study examines state practices in returning terrorists to the places where 
they have committed their crimes. The final section is devoted to conclusions and recommendations regarding law.

Edward F. Mickolus, Todd Sandler, and Jean M. Murdock have co-authored International Terrorism in the 1980's: A Chronology of Events (1989). This two-volume work provides comprehensive descriptions of worldwide terrorist incidents from 1980-1983 (volume 1) and 1986-1987 (volume 2). The chronology includes more than transnational terrorist incidents; it also contains policy announcements relevant to the fight against terrorism. In particular, new laws enacted to combat terrorism are included, as are intergovernment agreements to cooperate in thwarting terrorism. The introduction aids the reader in using the chronology. This work will be helpful for policy makers, researchers and scholars in understanding the threat posed by international terrorism.

Who finances terrorists? How and from where do they get their money; how do they spend it; how do the superpowers and their allies get involved in financing terrorist organizations? James Adams, a correspondent of the Sunday Times of London, gives the answers to these questions in his The Financing of Terror (1986). In this work, the author discusses the financial resources of different terrorist organizations. This volume is not an exhaustive study of each terrorist group; however, it gives a basic outline for further investigation of this topic.

\section{PSYCHOLOGICAL ASPECTS OF TERRORISM}

Analyses of terrorism from the perspective of readers is difficult. One man's terrorist is another man's freedom fighter. Where from one point of view the actions of a terrorist may seem to be a legitimate action of defense or an attempt to control criminal threats or acts, from another point of view such actions may be seen as oppression.

The psychological literature on terrorism suffers from many of these conceptual difficulties. Nevertheless, there have been a few attempts to develop a psychological analysis of the terrorist, and the conditions that give rise to terrorism. Maxwell Taylor has held the Chair of Applied Psychology at University College, Cork, since 1983. Taylor is the author of many publications including a wide range of contributions on the application of psychology to the work of police and security services, with particular reference to terrorism, a subject which he has also studied in several European countries. In one of his books, The Terrorist (1988), he tries to develop a psychological understanding of the concept of terrorism. The book looks from a psychological point of view at some of the issues related to violent political extremist behavior. Most of the discussion focuses on the contemporary problem of terrorism, its conceptual basis, and a review of the psychological literature addressing the problem. Taylor presents various ways of thinking about terrorists and their actions. In chapters two and three, he examines the nature and scope of terrorism. A more individual perspective is then introduced in chapter four, where the role of mental illness is considered as an explanation of terrorism. Fanaticism as an explanation is explored in chapter five. Social and psychological generalizations about terrorists are reviewed in chapter six, and individual accounts of particular terrorists are discussed in chapter seven. Finally, in chapters eight and nine, alternative ways of thinking about terrorism are presented in terms of psychological and behavioral analysis, emphasizing the role of the context and consequences of terror ism in sustaining and developing terrorist behavior. The book includes a comprehensive bibliography and index. It would be valuable to academic as well as special and public libraries. 
Another fascinating account written about the psychology of the terrorist is Group Processes and Intergroup Relations (1987), edited by Clyde Hendrick. This work is issued as volume nine in the series "Review of Personality and Social Psychology." The book is a collection of essays written by different authors. The section of the book that deals with terrorism is chapter ten, "Social Psychology of Terrorist Groups," written by Clark R. McCauley and Mary E. Segal. Both authors have Ph.Ds in social psychology from the University of Pennsylvania. McCauley's area of interest is the dynamics of terrorist groups. Segal's research focuses on the effects of the environment on social networks and on individual differences in person perception. In this chapter, the authors provide us with an excellent analysis of terrorism from a social psychology point of view. They indicate that terrorism is not a function of individual psychopathology. Rather, it appears to be the outcome of traditional vehicles of group dynamics. The authors provide parallels to terrorist group socialization through analyses of religious cults, the group opinion extremity shift, and obedience to authority. The chapter ends with a useful bibliography.

Much research has been devoted to examining what terrorists have done in the past and what they might do in the future. Less attention, however, has been focused on what terrorists say about themselves - their mindset and decision-making processes. Bonnie Cordes, in When Terrorists Do the Talking: Reflections on Terrorist Literature (1987), discusses this point. She believes that much information about terrorist thinking and decision-making can be gleaned from the primary materials provided by the terrorists themselves, such as memoirs, statements, interviews, and communiques. The author's analysis of terrorist literature suggests how terrorists see themselves, what they think they are doing, and what they think their actions will accomplish. The analysis also proposes a simple framework for a more systematic examination of the terrorists' views of themselves and their actions.

The study of terrorist organizations as composed of persons who agree on all essential matters is discussed in Inside Terrorist Organizations (1988), edited by David C. Rapoport. This sociological account of motivation and justification is composed of a group of essays and case studies that analyze several groups. The contributors concentrate on "the context in which the terrorist operates, namely the role of revolutionary traditions and various cultural milieux in shaping self-perceptions and expectations." (p. 2) In the first part, "Internal Structure and Conflict," the authors highlight a feature present in virtually all human organizations. The second part deals with motivations and justifications of terrorist organizations. Although all of the essays are outstanding, several are particularly noteworthy. The first is the editor's "The International World as Some Terrorists Have Seen It: A Look at a Century of Memories." In this essay, Rapoport explains why terrorists have believed that their political purpose was better served by entering the international arena and what cost those decisions imposed. Mark Juergensmeyer's "The Logic of Religious Violence"; Ehud Sprinzak's "From Messianic Pioneering to Vigilante Terrorism: The Case of the Gush Emunim Underground"; and Khachig Tololyan's "Cultural Narrative and Motivation of the Terrorist" concentrate on the connection between religion and terrorist activities, emphasizing that, prior to the French Revolution, terrorist activities that were justified had to be justified in religious terms. Mark Juergensmeyer used Sikhs to illustratesacred terror. The analysis is logical and could be used as a basis for another work on analysis of other terrorist organizations from a psychological point of view. 


\section{Religious Aspects of Terrorism}

Terrorist activity raises a wide range of moral questions. What is the moral climate that produces terrorism? What are the doctrines terrorists use to justify themselves? What are the moral predicaments terrorists create? Unfortunately, the problem of violence related to religion has been neglected by historians of religion and religious studies specialists. Even what has been written by other specialists in the literature gives little understanding or analysis of the problem of religion in association with terrorism. The authors of The Morality of Terrorism: Religious and Secular Justifications (2nd ed., 1989), edited by David C. Rapoport and Yonah Alexander, address these religious aspects in their essays. They provide historical case studies that illustrate the issues created by the use of terror for different secular and religious purposes. The term "moral" has been used to refer to descriptions of circumstances, such as the moral context terrorists thrive in, or the moral pictures they have of their world; the relationship between religious and secular justifying doctrines; and explanations of how the process of attracting moral sympathy by committing outrageous actions works. The book is divided into three sections. The first treats religious terror. The second and third deal with the two major secular forms, state and rebel terror. Each section includes an introduction that describes the individual essays in some detail and discusses their mutual relationships. This second edition features two new essays: "The Study of Religion and Violence" by Richard C. Martin; and "Justifications and Means: The Moral Dimension of State-Sponsored Terrorism" by Grant Wardlaw. This volume provides important readings about the moral matters related to terrorism.

"Moral and Religious Aspects" is an important part of the book Contemporary Research on Terrorism (1989), co-edited by Paul Wilkinson and Alasdair M. Stewart. It includes four well-written essays: "Liberation Theology, Politics and Violence in Latin America" by R. W. Taylor; "Religious Violence in Islam, Towards an Understanding of the Discourse on Jihad in Modern Egypt" by R. C. Martin; "Why Does Religious Messianism Produce Terror" by D.C. Rapoport; and "Martyrdom as Legitimacy, Terrorism, Religion and Symbolic Appropriation in the Armenian Diaspora" by K. Tololyan.

In Holy Terror: Inside the World of Islamic Terrorism (1987) Amir Taheri, the former editor of Iran's largest newspaper, discusses the history and religious beliefs of Iran's Islamic fundamentalists. Daniel Pipes mentions in his review of this work (Commentary 85:76 April 1988) that Taheri's "insight into the arcane world of Iranian leadership and his journalist's eye for striking detail make his book an important source for ascertaining the impact of the Ayatollah Khomeini's regime on both Iran and the Muslim world."

\section{Combating Terrorism}

After having discussed terrorism from these various perspectives, it is now time to think about how these actions can be prevented. Despite the success of a number of governments in combating terrorists by increasing the security around their facilities, statistics show that every day terrorism is still growing tremendously. How to prevent terrorism is still a complicated issue. Several authors have treated the problem from different viewpoints. Geoffrey M. Levitt has held various government positions and served as counsel to the Office for Combating Terrorism from 
1983-1986. He has published several articles on the legal aspects of terrorism and has authored the book Democracies Against Terror: The Western Response to State-Supported Terrorism (1988). In this work, Levitt examines the efforts made by the major western democracies to cooperate in isolating, deterring, and punishing states that support international terrorism. He traces the Summit Seven (cooperation among the non-communist world's seven largest economic and political powers) initiatives on terrorism. He discusses the Summit declarations on various forms of terrorism and describes the political and technical follow-ups to these declarations by the governments involved. He also analyzes the actions of the seven governments in regard to selected terrorist incidents (airline hijackings, the London Libyan People's Bureau shooting, the Berlin discotheque bombing, and the El-Al bombing attempt). In the conclusion, he discusses the essential elements of a collective response to state-supported terrorism.

Another work concerning the problem of preventing terrorism is Terrorism and Personal Protection (1985), edited by Brian M. Jenkins, one of the world's leading authorities on international terrorism. Jenkins currently directs the Rand Corporation's Research Program on Subnational Conflict and Political Violence. Twenty-eight authors have contributed to this volume, which reflects the diverse aspects of the problem of terrorism and security. The authors give an overview of the kidnapping problem as it has affected various countries in order to illustrate the nature of the threat and its effect. They discuss the issues that management faces in dealing with kidnappings, including the costs associated with preventing and handling terrorist attacks. The problem of negotiations in a kidnapping episode, the technical issues of security, the principal domain of the security officer, and the requirements of security at the potential target's office are discussed. Part five of the study is devoted to the issues related to personal security and how to avoid or survive captivity. The conclusion addresses the difficulties faced by the returning hostage. The book is a good resource for researchers and academic libraries.

The Rand Library Collection presents A Conceptual Framework for Analyzing Terrorist Groups (1985), by Bonnie Cordes, Brian M. Jenkins, and Konrad Kellen with Gail Bass. The authors of this work use databases to develop a framework for the analysis of terrorist groups. They have divided their study into six parts. Part one describes Rand's attempt to develop a framework for analysis, to create the necessary database, and to apply methodology to broad questions of primary concern in combating terrorism. Part two describes the authors' attribute list and its codebook variant and discusses their use in analysis of terrorism groups. Part three outlines the data collection and evaluation process. In part four, a methodology is developed for applying the databases to identify the perpetrator of an unclaimed terrorist incident. Part five deals with identifying possible targets, tactics, and the level of sophistication of terrorists. Part six explores various ways in which the methodology can be developed to compare terrorist groups. The analysis is a valuable tool to researchers to help them in identifying nearly half of the unclaimed terrorist acts.

Terrorism is a war, and the ways to win it are found in two works: Gayle Rivers' The War Against the Terrorists: How to Win It (1987) and Terrorism: How the West Can Win (1987), edited by Benjamin Netanyahu. The War Against the Terrorists presents what the author perceives as the threat and what the western community must do to combat it. This book gives readers a taste of what may lie ahead. In Terrorism: How the West Can Win the authors outline ways to combat terrorism through international cooperation and intelligence-gathering among the democracies.

The Institute for East-West Security Studies in New York is one of the important centers bringing East and West together in sustained dialogue, study, and research on security issues. Martha Crenshaw, a specialist in international terrorism, was an American scholar-in-residence at 
this institute in 1987-1988. Currently, she is a professor of government at Wesleyan University. She wrote Terrorism and International Cooperation (1989) to provide us with a thoroughly readable assessment of the nature of terrorism and the possibilities and conditions for international cooperation in combating it. She concludes that the possibility for cooperation between East and West against terrorism exists, and that the international arrangements to prevent nuclear terrorism are already under way and may be considered a model for future cooperation.

Another important aspect of the terrorism problem can be found in Terrorism (1986), edited by Steven Anzovin. The authors of this work give a general introduction to the nature of terrorism and the influence of the media on terrorist activities. The most important part of this work is part four, "Fighting Back," which includes three essays on international support to prevent terrorism. Mark Whitaker offers ten practical recommendations for fighting terrorism; Abraham Safor outlines a plan for fighting terrorism through law; and the third essay presents the view of a number of scholars, writers, and policy makers on how to prevent and combat terrorist attacks.

With few exceptions, most of the aforementioned books do not focus on the deeply-rooted causes of terrorism. It is precisely for this deficiency that more research is needed to focus on the causes of terrorism.

\section{Periodicals}

Five major periodicals cover the subject of terrorism: Terrorism: An International Journal (1977-); TVI (Terrorism, Violence, Insurgency) Journal (1979-); International Terrorism Newsletter (1979-); Terrorism (1986-); and VAT (Violence, Aggression and Terrorism) (1987-).

Terrorism: An International Journal is published quarterly. It is a multidisciplinary journal devoted to the study of terrorism from political, economic, strategic, legal, philosophical, and psychological perspectives. TVI (Terrorism, Violence, Insurgency) Journal is published monthly and provides readable articles, a well-written book review section, updates on the activities of the most important groups, and a calendar of upcoming conferences and workshops likely to be of interest to criminologists, political scientists, and law enforcement personnel. It focuses on the operational or tactical aspects of terrorism as opposed to the theoretical or academic approach taken by Terrorism: An International Journal. Although both Terrorism and TVI have received excellent reviews, Bill Katz has stated in the reference tool Magazines for Libraries that Terrorism is the only scholarly publication devoted to the subject.

International Terrorism Newsletter, a monthly journal edited by Charles M. Hellelusch, issues special editions that include the current news issued by the News Clipping and Analysis Service of the United States Air Force. This service regularly reproduces newspaper and periodical articles, using sources like the FBI and the Congressional Quarterly Weekly Report.

John L. Scherer is the editor of the quarterly journal Terrorism, which began publication in 1986. The first two issues of the journal dealt with such topics as Libyan terrorism, attacks against the U.S. military, and attacks in Spain and the United States. In 1982, Scherer compiled a work called Terrorism: An Annual Survey. Although only two volumes were published, this serial remains useful, containing a chronology of terrorist incidents of 1981, descriptions of terrorist groups, and general information.

Finally, VAT (Violence, Aggression, and Terrorism is a quarterly, interdisciplinary, international forum with a broad editorial base. It focuses on terrorism and related phenomena. Some of the articles in die first volume address the relationship between crime and terrorism, state 
violence and terror, mythologizing terrorism, infrastructures of terrorist organizations, and sociological analysis of antiterrorist legislation in Western Europe.

All five of these journals are important for researchers interested in finding current information about terrorism.

Crane, Russak and Co., Inc. has published a series of journals in different subject areas. Among them, two are particularly relevant to the topic of terrorism: Conflict: An International Journal (1978-) and Political Communication and Persuasion (1980-). Both of these journals are published quarterly. Each issue of Conflict contains four or five generally well-documented and readable articles written by British and American authorities on violence and terrorism. Political Communication and Persuasion focuses on the influence of political communication and persuasion in the struggle for power within and among nations. Both journals are important for readers interested in the study of politically motivated violence and are highly recommended for academic, special, and public libraries.

Conflict Quarterly (1980-) is issued by the Centre for Conflict Studies, University of New Brunswick in Canada. It is a journal that provides remarkable insight into the workings of terrorism. Most of the articles examine international as well as internal conflict situations, such as terrorism and subversion, and the media's response to these acts.

The most popular general, mass circulation news magazines read by all kinds of readers are Time (1923-), Newsweek (1933-), and U.S. News and World Report (1933-). They are all published weekly and contain current information about what is happening in the world. They are highly recommended for all kinds of libraries. Readers will also find relevant literature about terrorism scattered throughout periodicals of diverse disciplines such as: World Press Review (1961-); World Politics: A Quarterly Journal of International Relations (1948-); Journal of Conflict Resolution (1957-); National Review (1955-); U.N. Monthly Chronicle (1964-); The Department of State Bulletin (1939- ); Congressional Quarterly Service Weekly Report (1965-); Journal of Peace Research (1964-); Comparative Politics (1968-); The New York Times Book Review (1890-); and Maclean's (1905-).

\section{Online Databases}

The searching of online databases is a time-saving technique that allows researchers to retrieve a greater number of documents that have a higher degree of relevance than those obtainable through manual search methods. Searches can be made as broad or as narrow as desired.

Many databases are available through the DIALOG Information Retrieval Service. ${ }^{1}$ This service has been helping users since 1972. Now, with more than 280 databases in a broad scope of disciplines available on the system, the DIALOG service offers unequaled subject balance and variety. The databases in the DIALOG system contain in excess of 120 million records. The service offers subject coverage, and provides indexes to book reviews, biographies, and directories, plus access to complete texts of articles. By using DIALOG, the researcher can search die following files which cover the subject of terrorists:

- LC MARC - BOOKS (Library of Congress MAchine-Readable Cataloging) — contains complete bibliographic records for all books cataloged by the Library of Congress since 1968. Materials cataloged before 1968 are covered by the RE-MARC (REtrospective 
MAchine-Readable Cataloging) database. LC MARC - BOOKS and REMARC provide access to a comprehensive, worldwide collection of books that can be searched by author, title, subject, series, publication date, and other access points.

- CIS (Congressional Information Service) (1970-) — provides current access to the contents of the entire spectrum of Congressional hearings and reports published by the House, Senate, and Joint Committees and Subcommittees each year. It is updated monthly.

- Legal Resource Index (1980-)—indexes articles, book reviews, case notes, president's pages, columns, letters to the editor, and bibliographical pieces.

- National Newspaper Index (1979-) — covers the full range of subjects found in the Washington Post, New York Times, and other national newspapers. It is useful for answering questions on general news.

- NCJRS (National Criminal Justice Reference Services) (1972- ) — covers all aspects of law enforcement and criminal justice such as police, courts, corrections, community crime prevention, and the criminal justice system. Cited documents include both U.S. and international research reports, published papers, books, and articles.

- PAIS International (1972-) - is the most important database which covers the subject of terrorism. It is a bibliographic index to the public policy literature of business, economics, finance, law, international relations, government, political science, and other social sciences. It has an enhanced combination of two print publications: PAIS Bulletin, which covers 800 English language journals and 6,000 non-serial publications (i.e., government documents, pamphlets, yearbooks, directories, and materials from the United States Congress), and PAIS Foreign Language Index, which covers 400 journals and 2,000 non-serial publications in English, French, German, Italian, Portuguese, and Spanish. The database includes printed materials in all formats: periodical articles; books; state, local, federal, and non-U.S. government documents; committee hearings; and reports of public and private organizations.

- Magazine Index (1959-) — covers more than 435 popular magazines and provides extensive coverage of current affairs, public relations, journalism, social sciences, and other areas. Magazine Index contains the full text of articles from more than 200 magazines from 1983 to the present.

- U.S. Political Science Documents (1975-) - provides detailed abstracts and indexing from approximately 150 of the major American journals which publish scholarly articles in the broad area of political science. It is an important database for finding information on terrorism.

- Books in Print (currently in-print books) - is the major source of information on books currently published and in print in the United States. This database provides a record of forthcoming books, books in print, and books out of print. Records in this database include basic bibliographic information. 
Other databases related to the subject of terrorism are: Newspaper Abstracts (1984-1988); Washington Post Electronic Edition (1983- ); Social Scisearch (1972-); Historical Abstracts (1973-); and Mideast File (1979-).

Two bibliographic files are available to users on-site at the Library of Congress. They are SCORPIO (Subject Content Oriented Retriever for Processing Information Online) and MUMS (MultipleUse MARC System). SCORPIO contains books, selected periodical articles, federal legislation, copyright registrations, and organizations. MUMS provides access to information in LC MARC - BOOKS and PREMARC, which contains references to books cataloged before the beginning of the LC MARC system and to serials cataloged prior to 1973. MUMS is broader in scope than SCORPIO, providing information about newer books yet to be acquired by LC. It also provides more access points to bibliographic records than SCORPIO.

\section{Bibliographies and Conclusion}

The literature of terrorism is rich. Scholars, researchers, and writers have approached the subject from different points of view and through various formats such as books, articles, bibliographies, government documents, and periodicals. Some authors have provided researchers with comprehensive works, while others have offered brief surveys of materials dealing with various aspects of terrorism. In terms of a general review of the literature, there are two basic, as well as comprehensive, bibliographies on terrorism: "A Bibliography of Political Terrorism" (1988) in Political Terrorism: A New Guide to Actors, Authors, Concepts, Data Bases, Theories and Literature (1988), by Alex Peter Schmid, and International Terrorism: A Bibliography (1986), by Amos Lakos. Schmid's bibliography covers different formats and is divided into the following major categories: bibliographies on terrorism and related forms of violence; conceptual, definitory and typological aspects of terrorism; general works on terrorism; regime terrorism and repression; insurgent terrorism; vigilante terrorism; other types of terrorism; terroristic activities by region and country; inter- and transnational terrorism; the terrorist personality and organization; victimological, psychological, criminological, military, juridical, and mass communication aspects; the etiology of terrorism's ideologies and doctrines of violence and violent liberation; counter-measures against terrorism; special forms of terrorism; and varia and related studies. The bibliography includes 5,831 entries. Lakos' International Terrorism: A Bibliography (1986) covers materials issued since the late 1960s. Lakos divided his bibliography into these broad categories: reference works, general works, theories of terrorism, psychological and social aspects, strategies and tactics, counter-measures, domestic and international aspects, the media and terrorism, nuclear terror threat, and geographical subdivision. Each category is divided into subsections which are then subdivided by form: books, journal articles, documents and reports including conference papers, government documents, and dissertations. Schmid's bibliography is more Europe-centered, while Lakos' bibliography concentrates more on American coverage. Access to information in these two bibliographies is provided by the detailed author and title indexes.

A selectively annotated bibliography compiled by Edward F. Mickolus with Peter $\mathrm{H}$. Flemming is Terrorism: 1980-1987 (1988). It is an update of a previous work entitled The Literature of Terrorism: A Selectively Annotated Bibliography which was published by Greenwood Press in 1980. Mickolus categorized the entries of the 1988 publication as follows: general treatments; tactics of terrorists; philosophical approaches; terrorist infrastructure; 
terrorism by geographic area; responses, media and terrorism; psychological and medical approaches; related studies; fiction; and bibliographies. Mickolus' bibliography includes in addition to English-language entries, citations from other languages with English translations of the titles if possible. Some of the citations are annotated. Access is through the author and title indexes.

There are two specialized bibliographies on terrorism. They are: Violence and Terror in the Mass Media: An Annotated Bibliography (1988), compiled by Nancy Signorielli and George Gerbner, and Global Terrorism: Historical Bibliography (1986), edited by Suzanne Robitaille Ontiveros. Signorielli and Gerbner are knowledgeable leaders in their field and their bibliography is the result of 4,600 requests that were mailed to scholars listed in the World Directory of Mass Communication Researchers. It includes articles published in scholarly journals, books, and popular periodicals, reports published by the United States and other governments, as well as some conference papers and relevant dissertations published through Spring 1987. The focus of the bibliography is on scholarly works relating to violence and terror. It includes four major areas of interest: violence and mass media content, violence and mass media effects, terrorism and the mass media, and pornography. Each citation contains a short abstract. Global Terrorism is published as one of the ABC-CLIO Research Guides, which are annotated bibliographies on high-interest topics in history and related social sciences. This bibliography contains 598 abstracts and citations of articles drawn from ABC-CLIO's history database which covers over 2,000 periodicals published in 90 countries. It is divided into 8 sections: an overview of terrorism in various countries, Europe, the Middle East, Asia, the Pacific Region, Latin America and the West Indies, North America, and Africa. Access to the abstracts and citations is provided by the ABC-SPIndex (Subject Profile Index) and an author index. Cross references in the form of see and see also references are also provided. Both bibliographies are intended for a specialized, scholarly audience.

Vance Bibliographies, in Monticello, Illinois, has published a series of bibliographies on very specific topics. The title of the series is "Public Administration Series: Bibliography." Among the series publications are International Aspects of Terrorism: A Bibliography (1989), by Mary Vance; Recent Military Views of Terrorism: A Selected Bibliography (1986), by Anthony G. White; Terrorism and Law: A Selected Bibliography of Articles, 1980-1985 (1986), by Dittakavi Nagasankara Rao; and The Nuclear Terrorism Threat: A Bibliography (1985), by Amos Lakos. Each of these bibliographies treats the subject of terrorism from specific aspects.

\section{Note}

1. See the Dialog Database Catalog. For more information on selecting a suitable database see the quarterly publication, The Directory of Online Databases.

\section{Works Cited}

This section includes several works not mentioned in the article, plus a few books published in 1989 or 1990 which were not yet available. 
Adams, James. The Financing of Terror: Behind the PLO, IRA, Red Brigades, and M-l9Stand the Paymasters. New York: Simon and Schuster, 1986. 293p. \$18.95. ISBN 0671497006. LC 86-10181.

Arnold, Terrell E. Think About Terrorism: The New Warfare. New York City: Walker and Co., 1988. 153p. ISBN 0802767575; 0802767583 pa. LC 87-21158.

Arnold, Terrell E. The Violence Formula: Why People Lend Sympathy and Support to Terrorism. Lexington, MA: Lexington Books, 1988. 202p. ISBN 0669131539. LC 86-45292.

Beyond the Iran-Contra Crisis: The Shape of U.S. Anti-Terrorism Policy in the Post-Reagan Era. Ed. by Neil C. Livingstone and Terrell E. Arnold. Lexington, MA: Lexington Books, 1988. 339p. ISBN $0669164666 ; 0669164674$ pa. LC 87-45376.

Chomsky, Noam. The Culture of Terrorism. Boston: South End Press, 1988. 269p. \$25; \$10 pa. ISBN 0896083357; 0896083349 pa. LC 87-28788.

Chomsky, Noam. Pirates \& Emperors: International Terrorism in the Real World. Montreal: Black Rose Books, 1987. 174p. \$29.95; \$14.95 pa. ISBN 0920057926; 0920057934 pa. LC cn87-90037.

Cline, Ray S. Terrorism: The Iranian Connection. Philadelphia: Taylor and Francis, Inc., 1988. \$29.95. ISBN 0844815233.

Cline, Ray S. Terrorism as State-Sponsored Covert Warfare. Fairfax, VA: Hero Books, 1986. 118p. ISBN 0915979195.

Combating the Terrorists: Democratic Responses to Political Violence. Ed. by H. H. Tucker. New York: Facts on File, 1988. 210p. \$24.95. ISBN 0816019015.

Comparative Politics. 1968-. Q. \$25. Pankwart A. Rustow. Subscription Fulfillment, Transaction Periodicals Consortium, Rutgers University, New Brunswick, NJ 08903.

Conflict: An International Journal. 1978-. Q. \$36. George K. Tanham. Crane, Russak and Co., Inc. 3 E. 44th St., New York, NY 10017.

Conflict Quarterly. 1980-.Q. \$12.50. David A. Charters. Center for Conflict Studies, University of New Brunswick, New Brunswick, Canada E3B 5A3.

Congressional Quarterly Service Weekly Report. 1965-. W. Price varies. Waynep.Kelley. Congressional Quarterly, Inc., 1414 22nd St. NW, Washington, DC 20037.

Contemporary Research on Terrorism. Ed. by Paul Wilkinson and Alasdair M. Stewart in association with George D. Smith. Aberdeen: Aberdeen University Press, 1989. 634p. £17.50. ISBN 0080366007 pa. LC gb89-43312. 
Cordes, Bonnie. A Conceptual Framework for Analyzing Terrorist Groups. Santa Monica, CA: Rand, 1985.114p. LC:85-199393.

Cordes, Bonnie. When Terrorists Do the Talking: Reflections on Terrorist Literature. Santa Monica, CA: Rand, 1987. 389p. LC 87-410983.

Crenshaw, Martha. Terrorism and International Cooperation. New York: Institute for East-West Security Studies; Boulder, CO: Distributed by Westview Press, 1989. 91p. \$7.95. ISBN 0913449113 (Institute); 0813377978 (Westview). LC 89-2132.

Current Perspectives on International Terrorism. Ed. by Robert O. Slater and Michael Stohl. New York: St. Martin's Press, 1988.220p. \$30. ISBN 0312013795. LC 87-23582.

The Department of State Bulletin. 1939-. M. \$19. U.S. Govt. Printing Office, Washington, DC 20602.

Dobson, Christopher. The Never-Ending War: Terrorism in the 80's. New York: Facts on File, 1989. 366p. ISBN 0816015376. LC 86-24093.

Dobson, Christopher. War without End: The Terrorists: An Intelligence Dossier. London: Sphere, 1987. 430p. £4.99. ISBN 0722167362 pa. LC gb88-14275.

Falk, Richard A. Revolutionaries and Functionaries: The Dual Face of Terrorism. New York: Dutton, 1988.222p. ISBN 0525246045. LC 87-25198.

Fighting Back: Winning the War Against Terrorism. Ed. by Neil C. Livingstone and Terrell E. Arnold. Lexington, MA: Lexington Books, 1986. 268p. ISBN 0669108081; 0669111392 pa. LC 85-18084.

Global Terrorism: A Historical Bibliography. Ed. by Suzanne Robitaille Ontiveros. Santa Barbara, CA: ABC-CLIO, 1986. \$31.50. ISBN 0874364531. LC 86-3339.

Golan, Galia. Gorbachev's "New Thinking" on Terrorism. New York: Praeger, 1989. ISBN 0275934632; 0275934640 pa. LC 89-23039.

Group Processes and Intergroup Relations. Ed. by Clyde Hendrick. Newbury Park, CA: Sage, 1987. 256p. ISBN 0803930909; 0803930917 pa. LC 88-138821.

Herman, Edward S. The Real Terror Network: Terrorism in Fact and Propaganda. Montreal: Black Rose Books, 1985. 252p. ISBN 0920057241.

Herman, Edward S. The Terrorism Industry: The Experts and Institutions That Shape Our View of Terror. New York: Pantheon Books, 1990. \$24.95; \$14.95 pa. ISBN 039458080X; 0679725598 pa. LC 89-42655. 
Inside Terrorist Organizations. Ed. by David C. Rapoport. New York: Columbia University Press, 1988.259p. \$35. ISBN 0231067208; 0231067216 pa. LC 87-27734.

International Conference on the Question of Terrorism (1987: Geneva, Switzerland). Terrorism and National Liberation: Proceedings of the International Conference on the Question of Terrorism. Ed. by Hans Köchler. Frankfurt am Main and New York: P. Lang, 1988. 318p. ISBN:3820412174. LC 88-196786.

International Task Force on Prevention of Nuclear Terrorism. Preventing Nuclear Terrorism: The Report and Papers of the International Task Force on Prevention of Nuclear Terrorism. Ed. by Paul Leventhal, and Yonah Alexander. Lexington, MA: Lexington Books, 1987. ISBN $0669148849 ; 0669148830$ pa. LC 86-46024.

The International Terrorism Newsletter. 1979-. M. \$24. The International Terrorism Newsletter, PO Box 22425, Louisville, KY 40222.

Journal of Conflict Resolution. 1957-. Q. \$45. Bruce M. Russett. Journal of Conflict Resolution, 2755 Beverly Dr., Beverly Hills, CA 90212.

Journal of Peace Research. 1964-. Q. \$28. Peace Research Inst., Universitetsforlaget, PO Box 258, Irvington-on-Hudson, NY 1053.

Lakos, Amos. International Terrorism: A Bibliography. Boulder, CO: Westview Press; London: Mansell Pub., 1986. 481p. \$37.50. ISBN 0813371570. LC 86-1719.

Lakos, Amos. The Nuclear Terrorism Threat: A Bibliography. Monticello, IL: Vance Bibliographies, 1985. ISBN 0890285799.

Laqueur, Walter. The Age of Terrorism. Boston: Little, Brown, 1987. 385p. \$19.95. ISBN 0316514780. LC 87-3652.

Levitt, Geoffrey M. Democracies against Terror: The Western Response to State-Supported Terrorism. New York: Praeger, 1988. 142p. ISBN 0275930211; 027593022X pa. LC 88-9859.

Maclean's. 1905-. Bi-M. \$14.75. Peter C. Newman. PO Box 1600, Sta. A, Toronto, Ontario, Canada M5W2B8.

McGurn, William. Terrorist or Freedom Fighter? The Cost of Confusion. London: Alliance Pub. for the Institute for European Defence \& Strategic Studies, 1987. 59p. ISBN 0907967833.

Mickolus, Edward F. International Terrorism in the I980's: A Chronology of Events. Ames: Iowa State University Press, 1989. 2 vols. ISBN 0813800242 (v. 1); 0813801729 (v. 2). LC 88-19891.

Mickolus, Edward F. Terrorism, 1980-1987: A Selectively Annotated Bibliography. New York: Greenwood Press, 1988. 314p. ISBN 0313262489. LC 87-32275. 
The Morality ofTerrorism: Religious and Secular Justifications. Ed. by David C. Rapoport and Yonah Alexander. New York: Columbia University Press, 1989. ISBN 0231067526. LC 88-30795.

Multidimensional Terrorism. Ed. by Martin Slann and Bernard Schechterman. Boulder, CO: L. Rienner, 1987. 138p. ISBN 1555870309. LC 87-4898.

Murphy, John Francis. Punishing International Terrorists: The Legal Frameworkfor Policy Initiatives. Totowa, $\mathrm{NJ}$ :

Rowman \& Allanheld, 1985. 142p. \$29.95. ISBN 0847674495. LC 85-15845.

Murphy, John Francis. State Support of International Terrorism: Legal, Political, and Economic Dimensions. Boulder, CO: Westview; London: Mansell, 1989. 128p. \$25. ISBN 0720120152. LC gb89-29870.

Nagasankara Rao, Dittakavi. Terrorism and Law: A Selected Bibliography of Articles, 1980-1985. Monticello, IL: Vance Bibliographies, 1986. 1Op. ISBN 0890289182 pa. LC 86-204110.

National Review. 1955-. Bi-W. \$24. William F. Buckley, Jr. National Review, Inc., 150 E. 35th St., New York, NY 10016.

The New York Times Book Review. 1890-. W. \$18. Harvey Shapiro. The New York Times, 229 W. 43rd St., New York, NY 10036.

Newsweek. 1933-. W. \$32.50. Lester Bornstein. Newsweek, Inc., 444 Madison Ave., New York, NY 10022.

O'Ballance, Edgar. Terrorism in the 1980's. London: Arms and Armour Press; New York: Distributed in the USA by Sterling Pub. Co., 1989. 127p. ISBN 0853689253. LC 89-178665.

O'Brien, Conor Cruise. Passion and Cunning. Grafton, 1990. 304p. £4.99. ISBN 0586088717. LC gb89-56276.

Parry, Clive. Parry and Grant Encyclopaedic Dictionary of International Law. New York: Oceana Publications, 1986.564p. ISBN 0379208288; 0379208296pa. LC 85-21496.

Political Communication and Persuasion. 1980-. Q. \$40. Yonah Alexander. CraneRussak and Co., Inc., 3 E. 44th St., New York, NY 10017.

The Politics of Terrorism. Ed. by Michael Stohl. New York: M. Dekker, 1988. ISBN 0824778146. LC 87-27578.

The Politics of Terrorism: Terror as a State and Revolutionary Strategy. Ed. by Barry Rubin. Lanham and London: University Press of America, 1989. 250p. £28.50; £14.95pa.

ISBN:0941700453;0941700445pa. LC gb89-8039. 
Rivers, Gayle. The War against the Terrorists: How to Win It. New York: Charter Books, 1987. 256p. \$3.95. ISBN 0441871879 pa.

Rosie, George. The Directory of International Terrorism. New York: Paragon House, 1987. 310p. ISBN 0913729299. LC 86-25211.

Rubenstein, Richard E. Alchemists ofRevolution: Terrorism in the Modern World. New York: Basic Books, 1987. 266p. ISBN 0465000959. LC 86-47740.

Schmid, Alex Peter. Political Terrorism: A New Guide to Actors, Authors, Concepts, Databases, Theories, and Literature. Amsterdam and New York: North-Holland Pub. Co.; New Brunswick (USA): Transaction Books, distributors for the Western Hemisphere, 1988. 700p. ISBN 0444856595. LC 89-129308.

Sederberg, Peter C. Terrorist Myths: Illusion, Rhetoric, and Reality. Englewood Cliffs, NJ: Prentice Hall, 1989. 168p. \$14. ISBN 0139068015. LC 88-17883.

Segaller, Stephen. Invisible Armies: Terrorism into the 1990's. San Diego: Harcourt Brace Jovanovich, 1987. 311p. \$17.95. ISBN 0151452881. LC 86-31845.

Signorielli, Nancy. Violence and Terror in the Mass Media: An Annotated Bibliography. New York: Greenwood Press, 1988. 233p. ISBN 0313261202. LC 87-29556.

Simon, Jeffrey David. Misperceiving the Terrorist Threat. Santa Monica, CA: Rand, 1987. 17p. ISBN 0833008471 pa. LC 87-9801.

TVI (Terrorism, Violence, Insurgency) Journal. 1979-. M. \$57. Mark Monday, PO Box 3830, San Diego, CA 92103.

Taheri, Amir. Holy Terror: Inside the World of Islamic Terrorism. Bethesda, MD: Adler \& Adler, 1987. 332p. ISBN 0917561457. LC 87-1297.

Taylor, Maxwell. The Terrorist. London and Washington: Brassey's Defence Publications, 1988. 205p. \$22.50. ISBN 0080336035. LC 87-34154.

Terrible Beyond Endurance?: The Foreign Policy of State Terrorism. Ed. by Michael Stohl and George A. Lopez. New York: Greenwood Press, 1988. 360p. ISBN 0313252971. LC 87-251.

Terrorism. Ed. by Steven Anzovin. New York: H. W. Wilson, 1986. 192p. ISBN 0824207254 pa. LC Sell 126.

Terrorism. Ed. by John L. Scherer. 1986-. Q. Minneapolis, MN: John L. Scherer.

Terrorism: An Annual Survey. 1982-1983. A. J.L. Scherer, 4900 18th Ave. S., Minneapolis, MN 55417. 
Terrorism: An International Journal. 1977-. Q. \$40. Yonah Alexander. Crane, Russak and Co., Inc., 3 E. 44th St., New York, NY 10017.

Terrorism: How the West Can Win. Ed. by Benjamin Netanyahu. New York: Avon, 1987. 254p. \$4.50. ISBN 380703211.

Terrorism and International Order. Lawrence Freedman, et al. London: Royal Institute of International Affairs,

1986. 107p. \$10.95. ISBN 04152997X pa. LC gb88-39554.

Terrorism and Personal Protection. Ed. by Brian M. Jenkins. Boston: Butterworth Publishers, 1985. 451p. ISBN 0409951269. LC:84-14245.

Terrorism, Ideology, and Revolution. Ed. by Noel O'Sullivan. Brighton, Sussex: Wheatsheaf Books: Distributed by Harvester Press, 1986. 232p. ISBN 0745000576. LC 89-217435.

The Terrorism Reader: A Historical Anthology. Ed. by Walter Laqueur and Yonah Alexander. New York: NAL Penguin, 1987.405p. \$12.95. ISBN 0452008433 pa. LC 86-31089.

Terrorists or Freedom Fighters. Ed. by Ely Tavin and Yonah Alexander. Fairfax, VA: HERO Books, 1986. 164p. ISBN 0915979195; 0915979187. LC 89-165859.

Testing Theories of State Violence, State Terror, and Repression. Ed. by George A. Lopez, Michael Stohl, and David Carleton. Boulder, CO: Westview Press, 1989. ISBN 0813375258.

Thackrah, John Richard. Encyclopedia of Terrorism and Political Violence. New York: Routledge \& Kegan Paul,

1987. 308p. £14.95. ISBN 0710206593. LC 87-4304.

Thompson, Leroy. The Rescuers: The World's Top Anti-Terrorist Units. New York: Dell Publishers, 1988.246p. \$4.50. ISBN 0440201748 pa. LC 87-145296.

The Threat of Terrorism. Ed. by Juliet Lodge. Boulder, CO: Westview Press, 1988. 280p. ISBN 0813306426. LC 87-25414.

Time. 1923-. W. \$35. Henry Anatole Grunwald. Time, Inc., 3435 Wilshire Blvd., Los Angeles, CA 90010 .

U.N. Monthly Chronicle. 1964-.M. \$11. United Nations Publishing, R.M.A.-3315, New York, NY 10017.

U.S. News and World Report. 1933-. W. \$31. Marvin L. Stone. U.S. News and World Report, Inc., 2300 N. St. NW, Washington, DC 20037.

VAT (Violence, Aggression, Terrorism). 1987-. Q. \$115. DIA, 122 Carol St., Danbury, CT 06810. 
Vance, Mary A. International Aspects of Terrorism: A Bibliography. Monticello, IL: Vance Bibliographies, 1989. 17p. ISBN 0792003225 pa.

Wardlaw, Grant. Political Terrorism: Theory, Tactics, and Counter-Measures. Cambridge and New York: Cambridge University Press, 1989. ISBN 0521362962; 0521368413 pa. LC 88-20362.

White, Anthony G. Recent Military Views of Counter-Terrorism: A Selected Bibliography. Monticello, IL: Vance Bibliographies, 1986. 7p. \$3. ISBN 0890289204 pa.

Wilkinson, Paul. Terrorism and the Liberal State. New York: New York University Press, 1986. 322p. \$35.; \$12.50 pa. ISBN 0814792065; 0814792073 pa. LC 85-15303.

World Politics: A Quarterly Journal of International Relations. 1948-. Q. \$22.50. Elisabeth G. Lewin. Center of InternationalStudies, PrincetonUniversity Press, Princeton, NJ 08540.

World Press Review. 1961-. M. \$16. Margaret E. Bailey, 230 Park Ave., New York, NY 10017.

Hudiburg, Richard A. "Psychology of Computer Use: VII. Measuring Technostress:

Computer-Related Stress." PsychologicalReports64 (June 1989): 767-72.

The author developed the Computer Technology Hassles Scale (CTHS) to measure computer-related stress. In an effort to judge the relation of the scale to other measures, over 140 subjects were administered the Perceived Stress Scale (measuring global stress) and the Computer Attitude Scale. Correlations showed that the CTHS does measure a dimension of psychological stress and that computer stress increases with increased computer use.

\section{Notes}

1. Craig Brod, Technostress: The Human Cost of the Computer Revolution. (Reading, MA: Addison Wesley, 1984), 16.

2. Strategic Management of Technostress in an Information Society, ed. by Amarjit S. Sethi, Dennis H.J. Caro, and Randall S. Schuler. (Lewiston, NY: C.J. Hogrefe, 1987), 3,9.

3. A discussion of such plans can be found in Maynard Lowry and Phillip M. O'Brien's "Rubble with a Cause: Earthquake Preparedness in California," College \& Research Libraries News 51 (March 1990): 192-97.

4. Vernon L. Grose, Managing Risk Systematic Loss Prevention for Executives. (Englewood Cliffs, NJ: Prentice Hall, 1987).

5. Susan C. Curzon, Managing Change: A How-to-Do-It Manual for Planning, Implementing, and Evaluating Change in Libraries. (New York: Neal-Schuman Publishers, 1989), 90-92.

6. Brod, 16.

7. Sandra Champion, "Technostress: Technology's Toll," School Library Journal 35 (November 1988): 48-51.

8. William Gray Potter, "Impact of Technology on Library Jobs and Services," Library Software Review 9 (March-April 1990): 98.

9. Strategic Management, 4. 